\title{
The closed Lake Issyk-Kul as an indicator of global warming in Tien-Shan
}

\author{
Vladimir V. Romanovsky ${ }^{1}$, Saadat Tashbaeva ${ }^{1}$, Jean-François Crétaux ${ }^{2^{*}}$, \\ Stephane Calmant ${ }^{3}$, Vanessa Drolon ${ }^{4}$ \\ ${ }^{1}$ IWPH, Bishkek, Kyrgyzstan \\ ${ }^{2} \mathrm{CNES} /$ Legos, Toulouse, France; ${ }^{*}$ Corresponding author: jean-francois.cretaux@,legos.obs-mip.fr \\ ${ }^{3} \mathrm{IRD} /$ Legos, Toulouse, France \\ ${ }^{4} \mathrm{CNRS} /$ Legos, Toulouse, France
}

Received 1 December 2012; revised 5 January 2013; accepted 18 January 2013

Copyright (C) 2013 Vladimir V. Romanovsky et al. This is an open access article distributed under the Creative Commons Attribution License, which permits unrestricted use, distribution, and reproduction in any medium, provided the original work is properly cited.

\begin{abstract}
Lake Issyk-Kul is the seventh deepest lake in the world situated in Central Asia in the Tien-Shan Mountains at the elevation of $1607 \mathrm{~m}$ above sea level. This area belongs to Kyrgyzstan. From 1927 to 1997 the water level decreased by $3.4 \mathrm{~m}$, and increased by $0.93 \mathrm{~m}$ from 1997 to 2011 . The article analyzes the impact of the global warming on the Lake Issyk-Kul thermal regime and the components of its water balance: river discharge, precipitation, evaporation and lake level variations. It shows that the global warming has entailed the increase of the Lake Issyk-Kul water temperature down to the maximum depths, and river discharge increase due to the glaciers melting and the evaporation from the lake surface. The air temperature increase of $1^{\circ} \mathrm{C}$ results in river discharge increas and lake level rise of $44 \mathrm{~mm} / y e a r$ and surface evaporation increase of $88 \mathrm{~mm} / \mathrm{year}$. The Lake Issyk-Kul level increase after 1997, which takes place in the situation of global warming, was caused by the activation of the West air masses transport and increase of precipitation in autumn.
\end{abstract}

Keywords: Issyk-Kul Lake; Tyup; Jyrgalan; Chon-Kyzylsuu; Juuku Rivers; Karabatkak Glacier; Watershed; Glacier Discharge; Discharge Formation Zone; Water Balance

\section{INTRODUCTION}

Lake Issyk-Kul is the seventh deepest lake in the world situated in Central Asia in the Tien-Shan Mountains at the elevation of $1607 \mathrm{~m}$ above sea level. In the north and south, it is surrounded by Kungei-Alatoo and Terskei-Alatoo ranges accordingly, elevating up to 2000 $3500 \mathrm{~m}$ above the lake. This area belongs to Kyrgyzstan. The length of the lake is $178 \mathrm{~km}$, width- $58 \mathrm{~km}$, maximum depth-668 m; the area is $6247 \mathrm{~km}^{2}$; and the volume of water is $1739 \mathrm{~km}^{3}$. The lake level records of the Issyk-Kul have started in 1926. From 1927 to 1997, its level decreased by $3.4 \mathrm{~m}$, and from 1997 to 2011, it increased by $0.93 \mathrm{~m}$.

It is well known that the water level variations of closed lakes are the resulting product of the moisture in their basins. The subject of this work is to study the influence of global warming on the thermal regime, water level variations and the components of the lake water balance.

Lake Issyk-Kul water balance formula is as follows:

$$
X+Q-B-E \pm \Delta h=0
$$

where $X$-precipitation; $Q$-river affluent from the discharge formation area, which is divided into $Q_{1}$ and $Q_{2}$ - surface and underground inflow to the lake, $B$ irrigation water losses, $E$-evaporation from the lake surface, $\Delta h$-lake level variations.

The data of hydrological stations, active and closed meteorological stations (Figure 1) were used for this research. In the last century, there were 14 meteorological stations (MSs) in the Issyk-Kul basin. Nowadays, there are only four: MS Balykchy (Rybachye), Cholpon-Ata, Kyzylsuu (Pokrovka) and Chon-Ashu. The observation series of two active meteorological stations in Balykchy and Cholpon-Ata were interrupted due to relocation in 1958 and 1971.

\section{AIR AND WATER TEMPERATURE OF LAKE ISSYK-KUL}

The previous studies at all active meteorological 


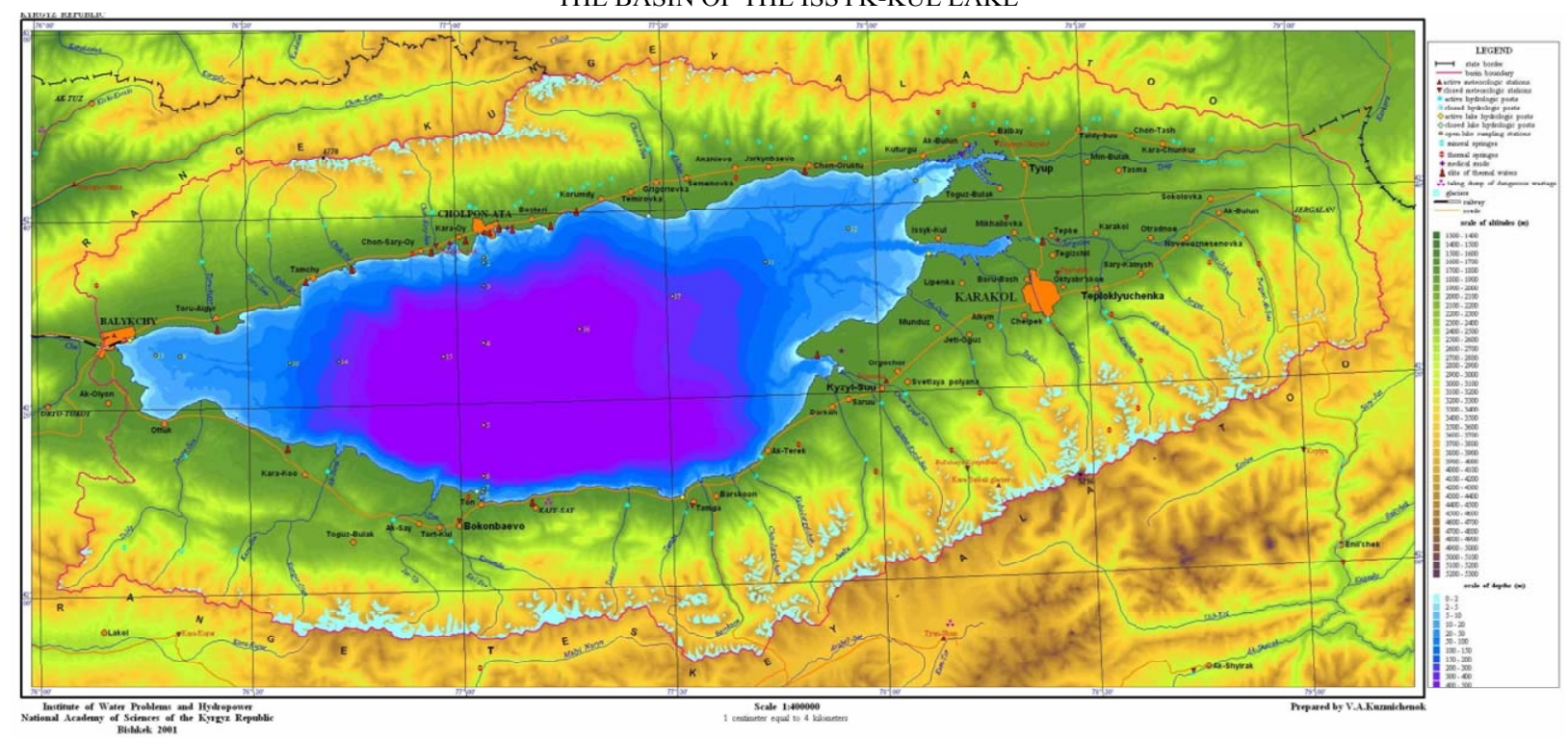

Figure 1. Hydrological stations, active and closed meteorological stations of the Issyk-Kul Basin.

stations in Kyrgyzstan and partly in Kazakhstan since 1927 have shown a trend of climate warming [1-5].

Let's consider the impact of global warming on the thermal regime of Issyk-Kul Lake, based on the data of the MS "Cholpon-Ata", which is located on the north shore at the distance of $100 \mathrm{~m}$ from the lake. The average monthly water temperature exceeds average monthly air temperature, because of the different air and water thermal capacity throughout the year (Figure 2).

The average annual air temperature is $8.3^{\circ} \mathrm{C}$, and water temperature is $12.1^{\circ} \mathrm{C}$. The maximum average monthly temperatures of the air $\left(18.3^{\circ} \mathrm{C}\right)$ and water $\left(20.6^{\circ} \mathrm{C}\right)$ are in July and August respectively, and the minimum average monthly temperatures of the air $\left(-1.9^{\circ} \mathrm{C}\right)$ and water $\left(4.7^{\circ} \mathrm{C}\right)$ are in January and February. The minimum difference between air and water temperatures $\left(1^{\circ} \mathrm{C}\right)$ was registered in May, and the maximum difference $\left(7^{\circ} \mathrm{C}\right)$ in January. The average annual and average February temperatures of the air and water show good correlation of 0.78 .

The trend analysis of air and water temperatures for the period of 1972-2009 (Figure 3(a)) shows that the trends of average monthly water temperatures were higher than the trends of average monthly air temperatures, except in February, March and May. The maximum trends of air temperatures correspond to maximum trends of water temperatures in February and March. Minimum trends of air temperatures correspond to maximum trends of water temperatures in July and August. During 38 years of observations (from 1972 to 2009), the February water temperature in Cholpon-Ata increased by $1.6^{\circ} \mathrm{C}$, and the February air temperature increased by $1.9^{\circ} \mathrm{C}$.

From (Figure 3(b)) the trends of water temperature measured in Cholpon Ata month by month are highlighted. It shows that principally winter and spring temperature has increased a lot over the last decades (see also Figure 3(c)) and that in the summer and early autumn the water temperature did not raise at this rate (with exception of June with very high increases between 2000 and 2005). In summer one also sees that there is an anomaly of positive water temperature in the middle of the 1980s.

Expedition of the Academy of Sciences of the USSR, under the guidance of Academician L.S. Berg, made the measurements water temperatures at various depths of Lake Issyk-Kul in 1928, 1930 and 1932. According to their data, in the area of maximum depths, the temperatures of $4.3^{\circ} \mathrm{C}$ and $4.2^{\circ} \mathrm{C}$ were registered at the depth of $200 \mathrm{~m}$ and $600 \mathrm{~m}$ respectively in $1928 ; 4.0^{\circ} \mathrm{C}$ and $3.7^{\circ} \mathrm{C}$ in $1930 ; 4.2^{\circ} \mathrm{C}$ and $3.7^{\circ} \mathrm{C}$ in 1932 [6].

Between 1981 and 1988, the routine measurements of water temperature at big depths were conducted by the Kyrgyz Department of Hydrometeorology from the "Moltur" research vessel. At that time, temperatures in the range $3.7^{\circ} \mathrm{C}-4.1^{\circ} \mathrm{C}$ were registered at the depth of $650 \mathrm{~m}[7,8]$. There were no large deviation of the water temperature at the depth of $200 \mathrm{~m}$ in 1928, 1930 and 1932.

After the long hiatus, the observations in 2003-2005 conducted under the ISTC ${ }^{1}$ KR-330/3 project registered its significant increase in central parts of the lake in the area of maximum depths. During 20 years (May 1983 May 2003), the water temperature increased by $0.3^{\circ} \mathrm{C}$ $1.0^{\circ} \mathrm{C}$ at all levels, except for the surface $10 \mathrm{~m}$ layer,

${ }^{1}$ International Science and Technical Center. 


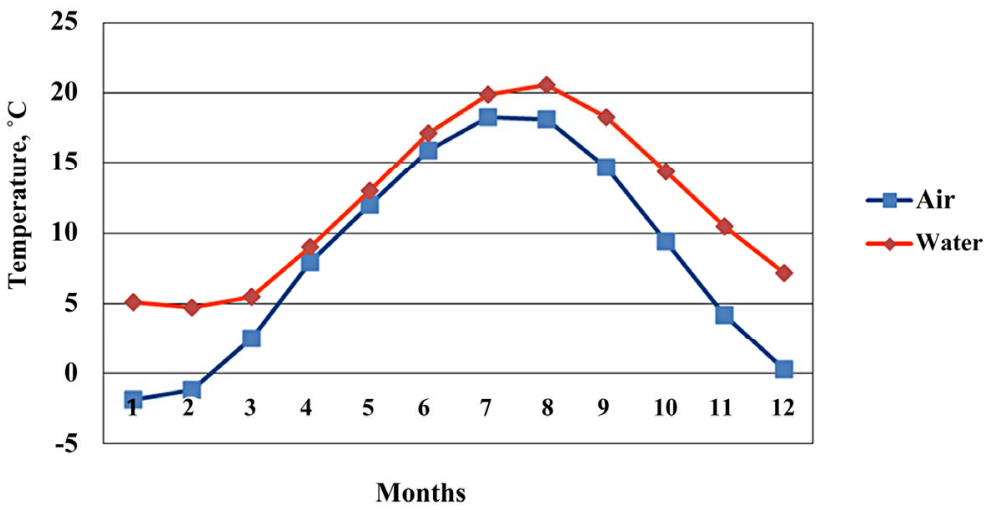

Figure 2. Intra-annual air and water temperature variations of Lake Issyk-Kul in Cholpon-Ata.

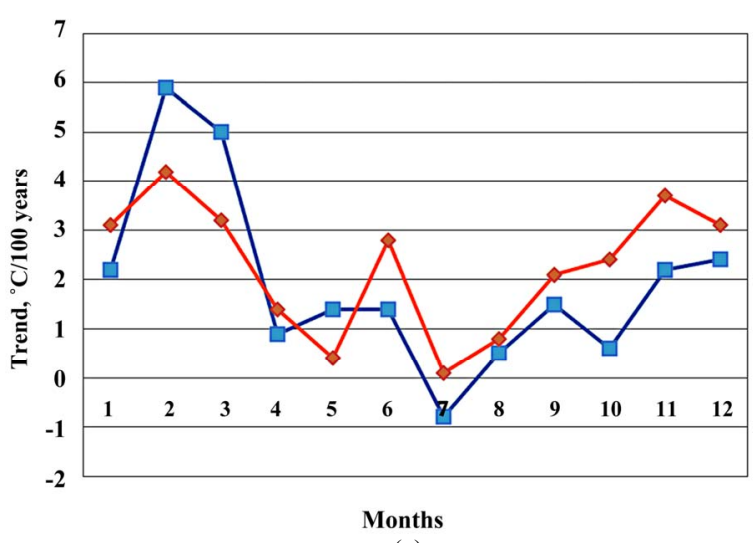

(a)

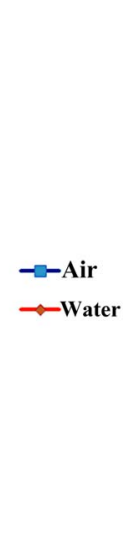

Cholpon Ata February temperature

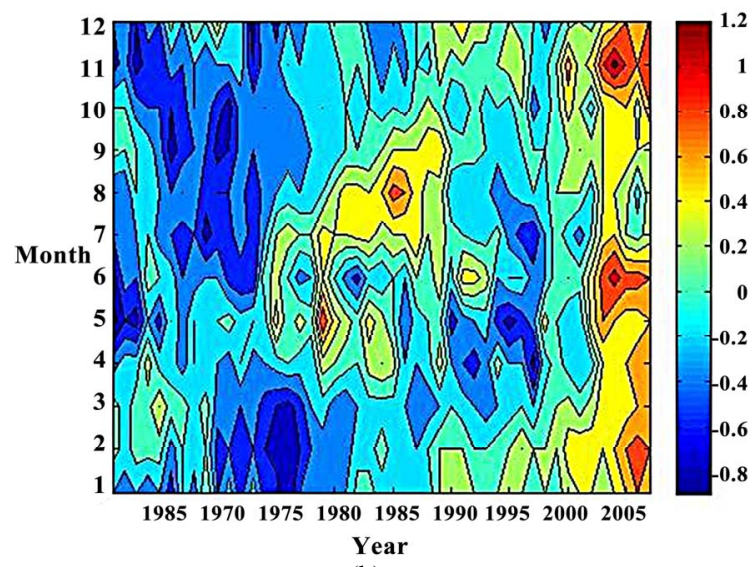

(b)

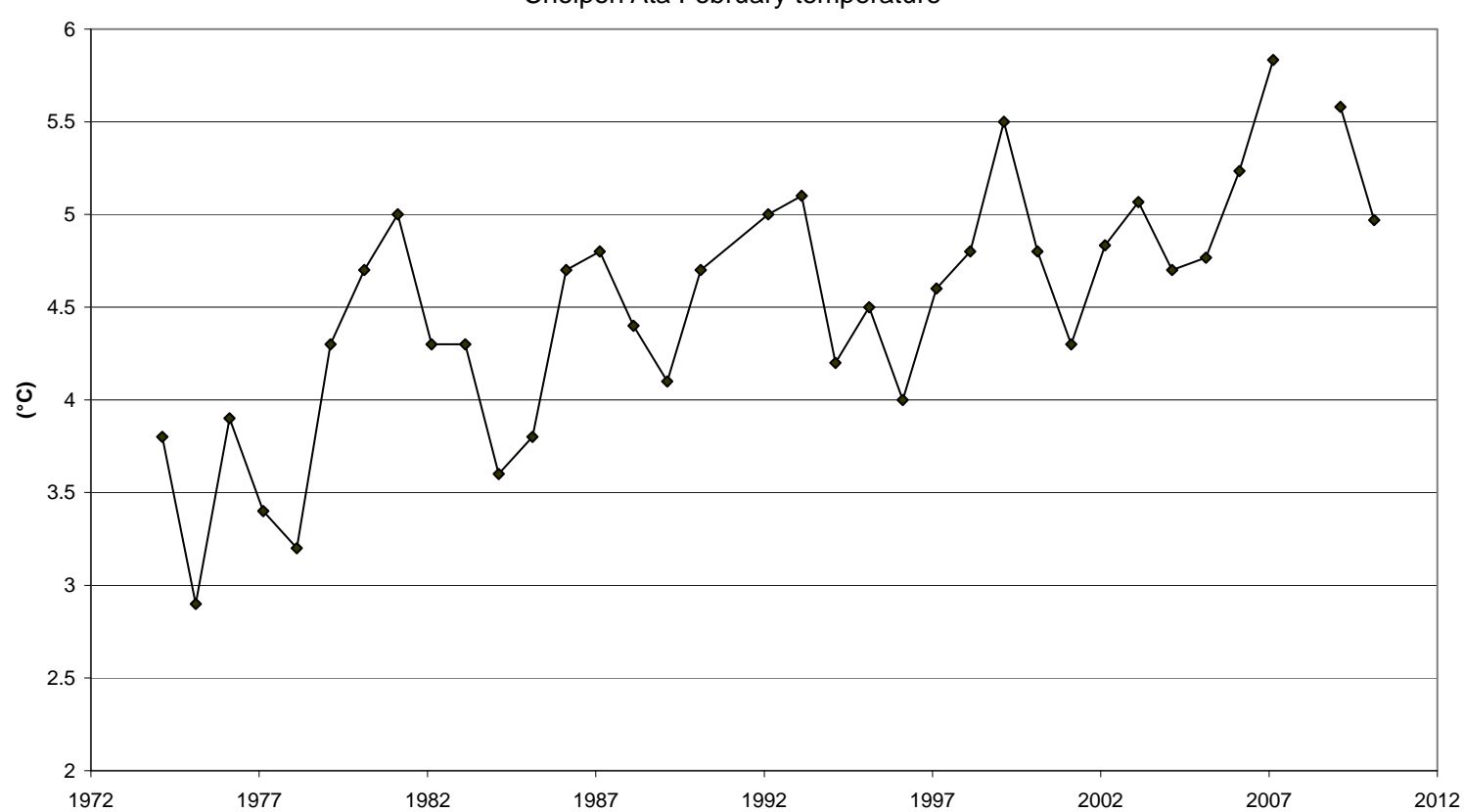

(c)

Figure 3. (a) Trends of the Lake Issyk-Kul's water temperature and air temperature in Cholpon-Ata; (b) Changes of water temperature in Cholpon Ata, from 1960 to $2005\left({ }^{\circ} \mathrm{C}\right)$ for each month of the years; and (c) Water temperature measured in Cholpon Ata in February. 
which rapidly responses to the weather conditions at the time of measurement [7] (Figure 4). At the maximum depth of $650 \mathrm{~m}$, the temperature increased by $0.5^{\circ} \mathrm{C}$.

Seasonal water temperature measurements in 20032005 showed the trend of increase in the deep zone. At the depth of $650 \mathrm{~m}$ in 2003 and 2004 , it was $4.4^{\circ} \mathrm{C}$, and $4.5^{\circ} \mathrm{C}$ in 2005 .

Air temperature is not an immediate component of water balance, but it determines the value of river discharge and the surface evaporation of Lake Issyk-Kul.

\section{RIVER DISCHARGE}

There are 4 types of rivers in the basin of the Lake Issyk-Kul based on their origins. Rivers with highly elevated catchment areas with glaciers, having seasonal floods in July-August during the glaciers melting, are of glacier-snow type. Rivers with lower catchment areas and less glaciation at the origins, having seasonal flood in June, when the snow at the middle altitude area is melting, are of snow-glacier type. The snow-feeding rivers have catchment areas at altitude 2000 - $3000 \mathrm{~m}$ and seasonal flood in April-May. Rivers of the lakeside plains, called the zone of flow dispersion, with the maximum water discharge in September-October, have ground water feeding type. The most of Lake Issyk-Kul basin rivers are of glacier-snow type. The snow-glacier type includes Jyrgalan River (until its confluence with the TurgenAksu River) and Oital. Tyup River has snow feeding type; ground water feeding type rivers are Karasu, Keklik and Karakoo. Among the rivers of glacier-snow type, one can distinguish the snow feeding phase in April-May, glacier feeding phase in July-August, and the most prolonged phase of ground water feeding from October to February. In addition, there are three transitional phases with mixed feeding: groundwater-snow feeding in March, snow-glacier feeding in June and glacier-groundwater feeding in September.

The high-altitude zone, the lower border of which is

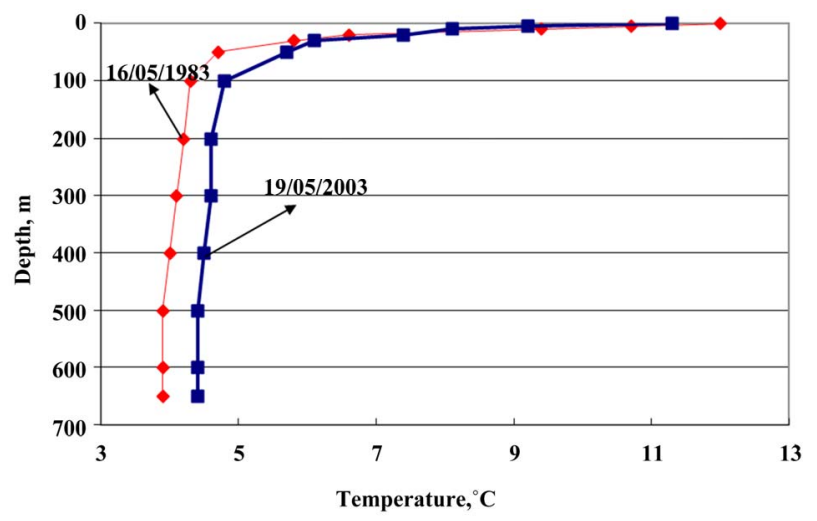

Figure 4. Water temperature in central part of Lake Issyk-Kul in May 1983 and 2003.
$3000 \mathrm{~m}$, is the main place for surface discharge formation. This zone gives $80 \%-87 \%$ of total amount of discharge. Glaciers discharge increase by $40 \%-90 \%$ in abnormal hot years, which in many cases not only compensates the discharge losses at the expense of precipitation, but also exceeds the normal rate.

The climatologist A.I. Voyeikov [9] has rightly noted that "rivers are the product of climate". If meteorological stations data characterize the climate in different points, the river discharge describes the interaction of precipitation and air temperature over the larger areas of river catchment.

To study the impact of global warming on the river discharge, the total discharge of 17 rivers of Lake IssykKul basin with the glacier-snow feeding was studied. There have been continuous series of observations from 1942 on those rivers. Hydrological stations on those 17 rivers are located above the water withdraw to irrigation. Thus, they are registering the undisturbed natural water discharge.

Rivers discharge is determined by precipitation, which fall in the catchment area, and by evaporation, which depends on air temperature. The higher the air temperature, the more the evaporation, and the lower the river discharge. But on rivers with the big glaciation area, high temperatures determine the active melting of glaciers. Therefore maximum discharges of the glacier feeding rivers are observed during the hottest period from July to August.

The connection between average monthly air temperature at the meteorological station of Tien-Shan, located in glacial-nival belt at the elevation of $3614 \mathrm{~m}$, with the total river discharge of 17 rivers in June, July, August and September is shown through linear equations (Figure 5). It shows that global climate warming makes crucial contribution to the current increase in river discharge.

The root-mean-square error in values of discharges of 17 rivers was \pm 19.8 in June (relative error $16.5 \%$ ), in July $\pm 18.6(11.6 \%)$, in August \pm 15.5 (10.2\%), in September $\pm 11.0(14.4 \%) \mathrm{m}^{3} / \mathrm{s}$. Given the fact that the water discharge measurement's relative error is $10 \%$, one can consider the accuracy of calculated river discharge as satisfactory. Measured and calculated discharges of 17 rivers of Lake Issyk-Kul basin, based on the air temperature of Tien-Shan meteorological stations, are shown in Figure 6.

According to the data of glaciologists A.N. Dikih and L.L. Dikih [10], at Kara-Batkak glacier, which is located in the headstream of the Chon-Kyzylsuu river, the annual value of the ice melting layer was $177 \mathrm{~cm}$ over the warm period in 1948-1972, and $210 \mathrm{~cm}$ in 1973-1991. The increase in the average glacier melt of $33 \mathrm{~cm}$ was associated with the significant rising of the snow line and 

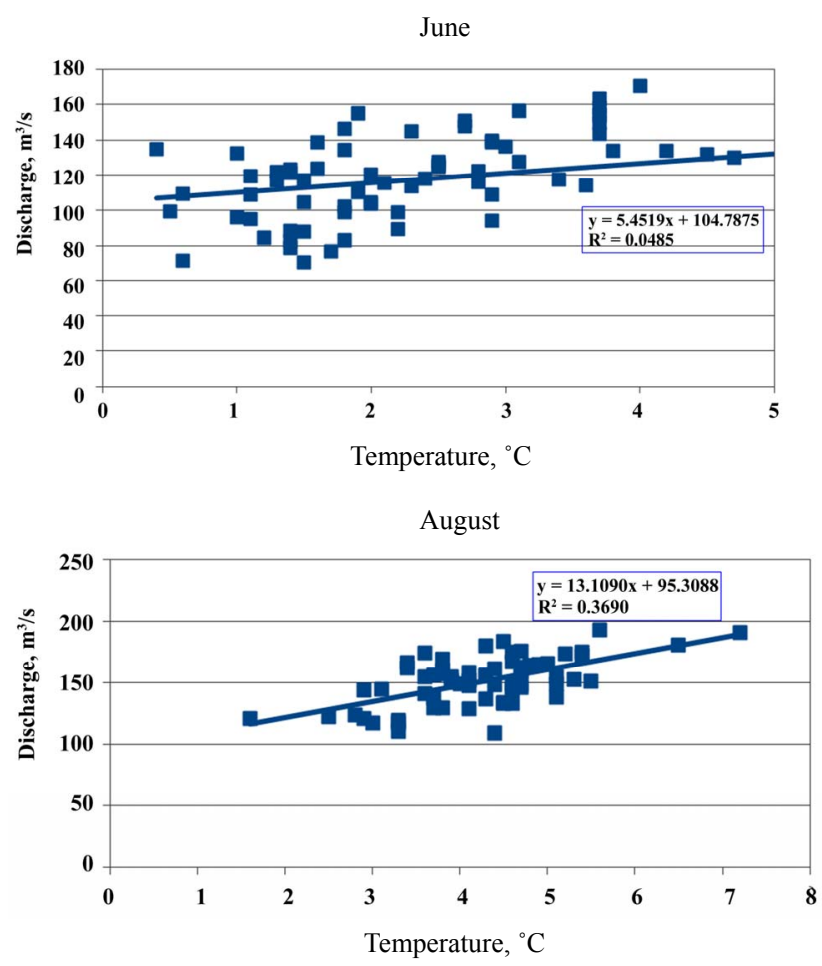
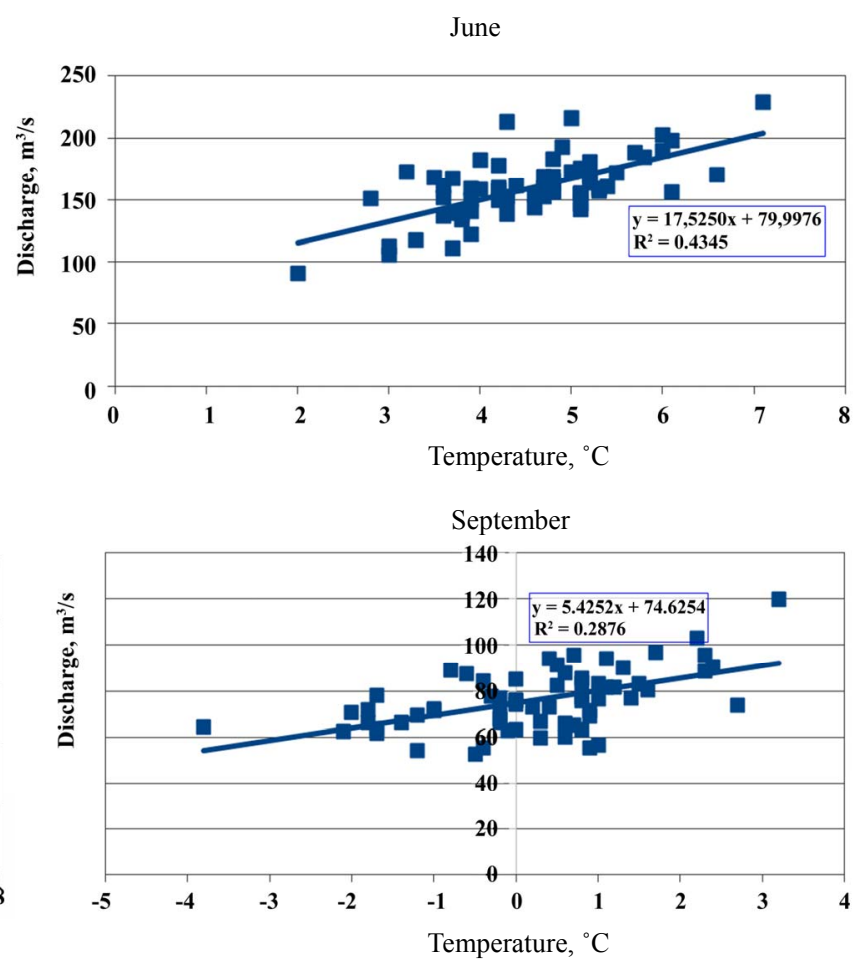

Figure 5. Connection between total discharges of 17 rivers in June, July, August and September and the corresponding temperature at the MS Tyan-Shan.

inclusion of additional areas into the active glacier melting. As a result, they increased the volume of the glacier melting water and its contribution to the total water discharge of the Chon-Kyzylsuu River. The proportion of the glacier water in summer discharge during the period of 1948-1972, was $38.7 \%$, and after 1972 it increased by $6 \%$.

The increase of the water discharge of glacier-snow feeding rivers in June-September corresponds to the sharp decrease in the accumulated mass balance of Karabatkak and Abramov Glaciers after 1972 (Figure 7) and to the increase in the speed of the glacier recession.

According to observations at Karabatkak glacier, the last year with the positive glacier mass balance was 1972.

During the period from 1942 to 1972, it was observed a significant trend of the discharge increase on 17 rivers in June, and negative trends in July, August, and September, which corresponded to the negative trends in air temperature. The annual discharge of 17 rivers during that period increased by $2.9 \mathrm{~m}^{3} / \mathrm{s}$. From 1972 to 2008, during the entire year, it was observed positive trends of the discharge of the rivers with the maximum augmentation in discharge in June and September 27.5 and 29.5 $\mathrm{m}^{3} / \mathrm{s}$ respectively, and annual discharge $14.1 \mathrm{~m}^{3} / \mathrm{s}$. During the cold season from October to March, the river discharge occurs at the expense of the underground water in river basins accumulated during the previous warm pe- riod. Therefore, during the groundwater feeding phase (from October to March) during the first time interval, we observed less statistically evident trends of the 17 rivers discharge, and during the second time interval, the trends increased $\left(R^{2}=0.62-0.67\right)$. During the period of October to February, pair correlation of the total average monthly discharges (for 17 rivers) approximates to 1 . This allows forecasting the discharge of the groundwater feeding phase from 1 to 5 months beforehand (Figure 8).

Good pair correlation $\left(R^{2}=0.57\right)$ is observed between September and October river discharges. As in September one can observe a clear trend to increasing river discharge after 1972, one can also observe the same trend in the river discharge during the cold period from October to March. During the period of 1972-2008, the inflow increase in October was up to $66.4 \%$, in November - up to $64.2 \%$, and from December to March inclusive - up to $40 \%$. A significant increase in water discharge in underground feeding was taking place during 1998-2008. Lake Issyk-Kul level rise was also noted during this period.

The increased discharge in underground feeding is connected with the increase in groundwater level of Lake Issyk-Kul basin and beyond it, in river valleys and intermountain valleys throughout Kyrgyzstan.

Thus, the increase in glacier discharge caused the regular increase of underground discharge. 


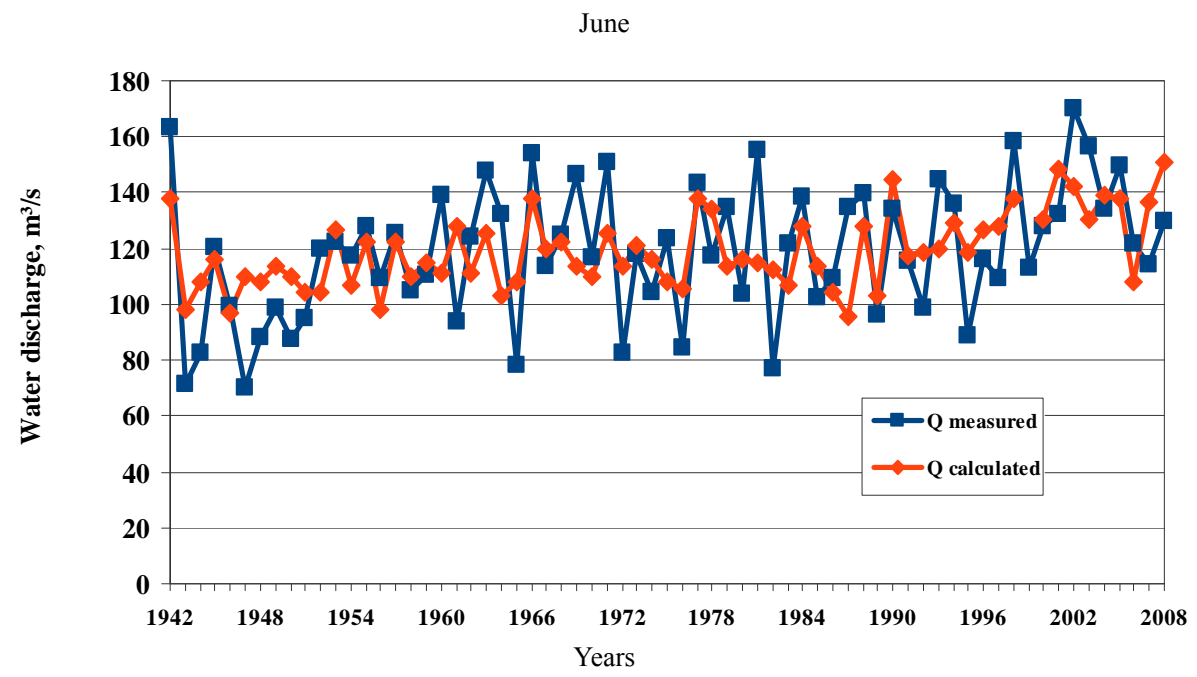

(a)

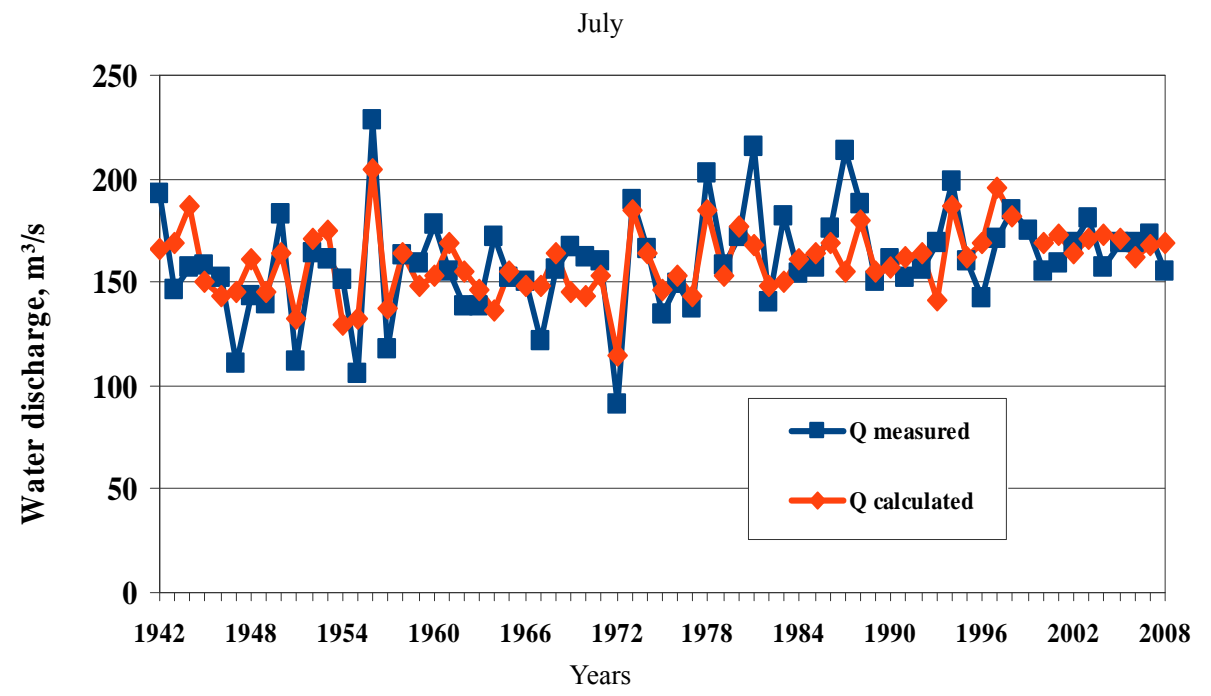

(b)

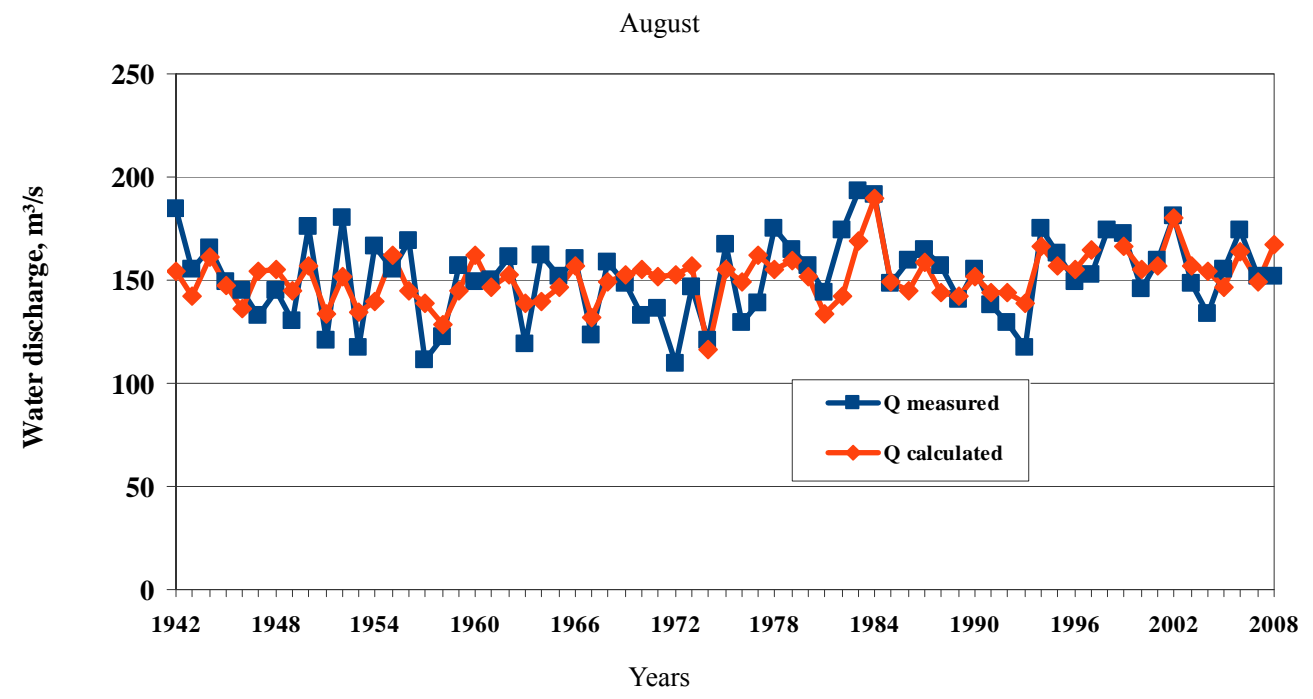

(c) 


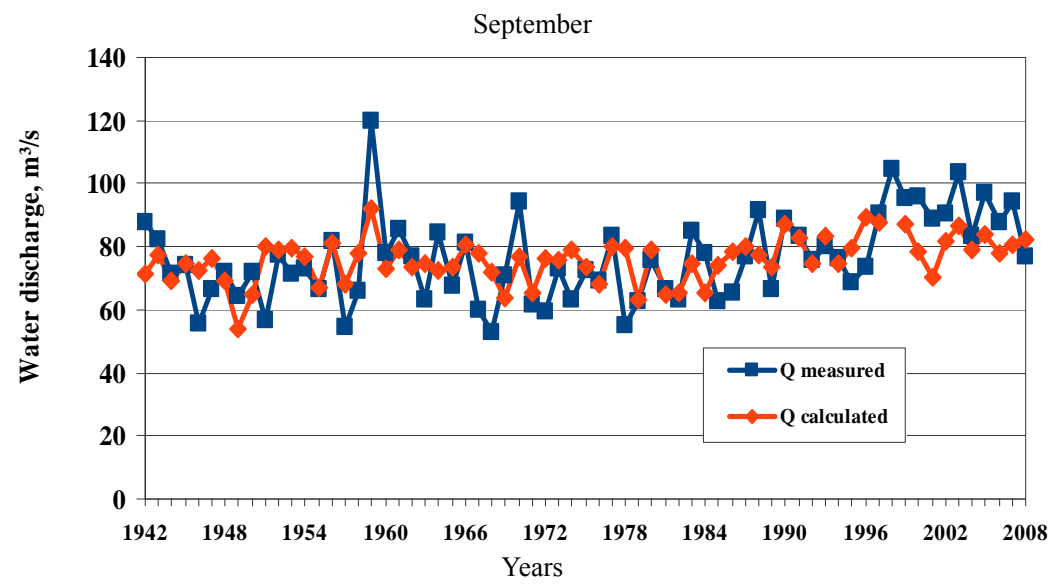

(d)

Figure 6. Measured and calculated total water discharges of 17 rivers of Lake Issyk-Kul basin in (a) June; (b) July; (c) August and (d) September.

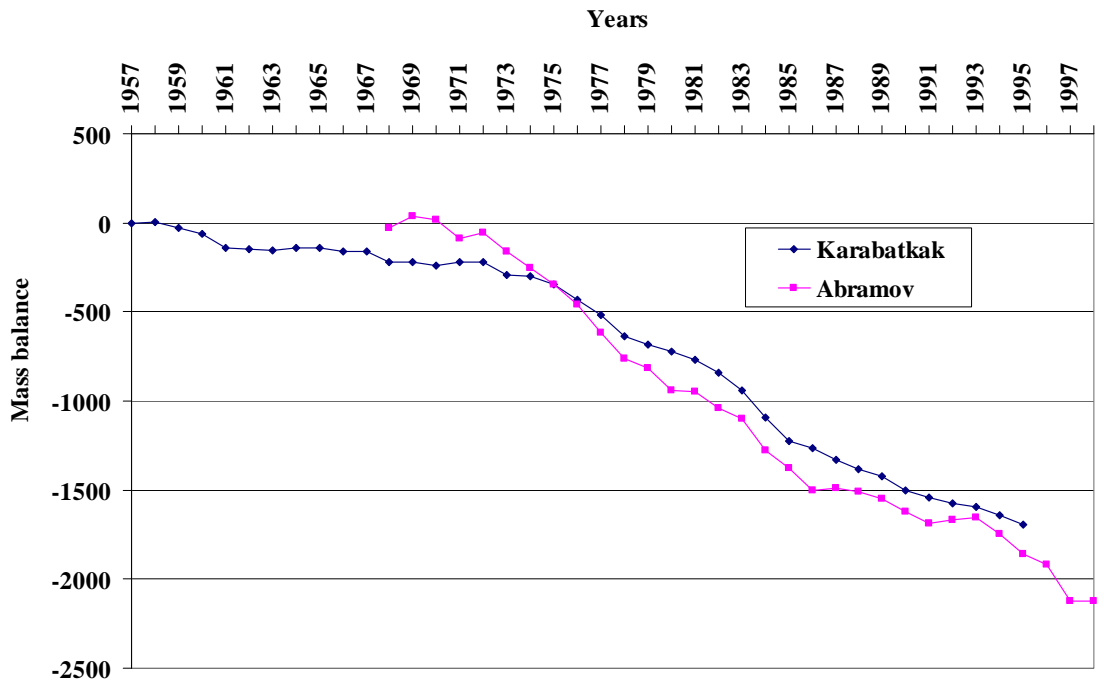

Figure 7. Karabatkak and Abramov Glaciers accumulated mass balance.

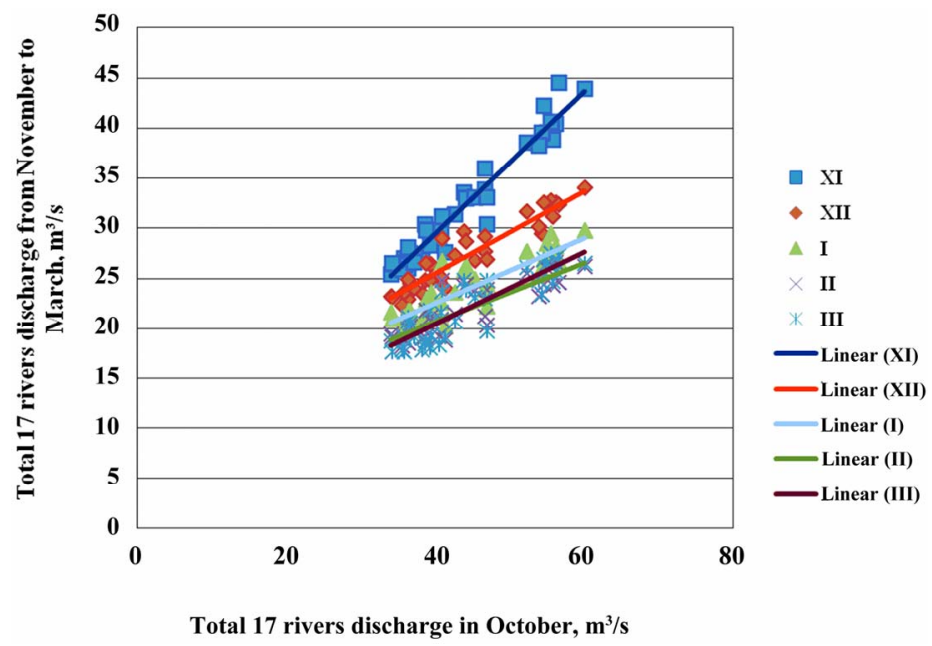

Figure 8. Relationship between river discharge in October and the 5 following months. 
Studying the modern global warming impact on the discharge mode of rivers with different types of feeding has significant importance, because rivers with a snow feeding type (whose basins do not have any glaciers) and rivers with a snow-glacier type of feeding (whose basins have negligible glaciation area) can serve as proxies for predicting the river discharge under the future global warming and considerable recession or complete disappearance of glaciers.

A series of observations of the climate have shown that the coldest year was 1972, and the hottest year was 1997. Summer and autumn (with the exception of November) temperatures in a lakeside plain, middle altitude areas and in glaciers were $0.5^{\circ} \mathrm{C}-2.5^{\circ} \mathrm{C}$ lower than the normal temperature in 1972, while in 1997, they were the same values higher than the normal one. In the upper streams of the Chon-Kyzylsuu River on Kara-batkak glacier, the positive average monthly temperature, under which melting took place, was observed even in October of 1997 (Figure 9).

In cold 1972, in the East of Lake Issyk-Kul basin at Balbai meteorological station, the precipitation was $27.8 \%$ above normal, and in hot 1997 , it was $17.6 \%$ below normal (Figure 10).

Under such climate conditions, the inflow to Lake Issyk-Kul from all the rivers of the discharge forming

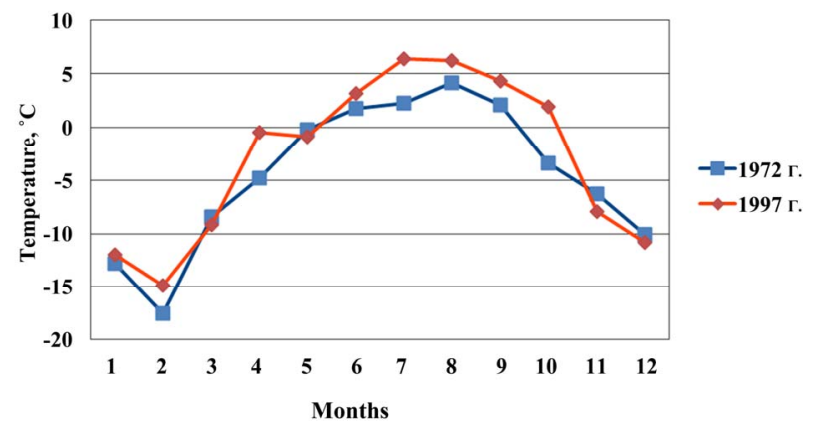

Figure 9. Air temperature in cold 1972 and hot 1997 on the Karabatkak glacier $(\mathrm{H}=3400 \mathrm{~m})$.

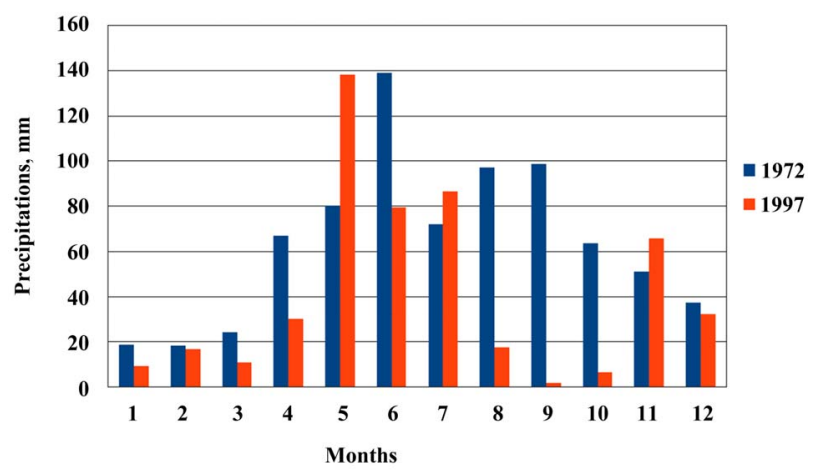

Figure 10. Precipitations in Balbai meteorological station in cold 1972 and hot 1997. area was $3.03 \mathrm{~km}^{3} /$ year in 1972 , and $4.04 \mathrm{~km}^{3} /$ year in 1997, which in conversion to the aquatic area of the lake corresponded to the water layer of $485 \mathrm{~mm}$ thick in 1972, and $653 \mathrm{~mm}$ in 1997. Thus, in spite of the exceptional dryness in 1997, the layers of river discharge into Lake Issyk-Kul was $168 \mathrm{~mm}$ more than during a colder and more humid year. This phenomenon relates to the fact that the largest part of Lake Issyk-Kul basin rivers have glacier type of feeding and high summer temperatures of 1997 that contributed to active glacier melting. The snow-line was 220 - 375 m higher in 1997 than in 1972 (Table 1), while in July and August, it reached the altitude of $3920 \mathrm{~m}$, where the maximum glaciation's area was located. In 1972, the altitude of the snow line was higher than the altitude of the firn line on the Karabatkak glacier located at the height of $3770 \mathrm{~m}$ in August, and in 1997, it was higher than that one in July, August and September.

The reaction of the snow feeding type Tyup river and snow-glacier feeding type Jyrgalan river (with the negligible glaciation area) to the climate change was completely opposite to that one of the glacier feeding type rivers, Chon-Kyzylsuu river (Figure 11).

On Tyup river, the average annual discharge during the cold and humid 1972 was $4.29 \mathrm{~m}^{3} / \mathrm{s}$ more than in 1997 , and on Jyrgalan river, it was $0.33 \mathrm{~m}^{3} / \mathrm{s}$ more, while on Chon-Kyzylsuu river with the glacier-snow feeding type, it was the opposite: the average annual discharge was $1.31 \mathrm{~m}^{3} / \mathrm{s}$ less in 1972 than in hot and dry 1997. In cold 1972 , the precipitation of the warm period fell on the rivers with the low watersheds (Tyup, Jyrgalan) mainly in liquid form and formed the river discharge. On the rivers with the high-altitude catchment (all the rivers with glacier feeding type) it fell mainly as snow and replenished the glacier mass balance.

From the above one can see that the rivers with different feeding type react to the modern climate warming in opposite ways. This conclusion is supported by the curve of river discharge dependence of the rivers of different feeding types on the air temperature in glacial-nival zone (Figures 12 and 13).

Figure 1 Dependence of the July discharges of the Tyup (Sarytologoi station), Jyrgalan (Sovetskoe station) and Juuku rivers on the air temperature in Tien-Shan meteorological station.

Thus, if temperatures at the glacial-nival zone increase by $1{ }^{\circ} \mathrm{C}$, the average monthly water discharge on the snow

Table 1. The snow-line altitude in 1972 и 1997, m.

\begin{tabular}{ccccc}
\hline Year/Month & June & July & August & September \\
\hline 1972 & 3520 & 3540 & 3830 & 3485 \\
1997 & 3740 & 3915 & 4160 & 3815 \\
Difference & 220 & 375 & 330 & 330 \\
\hline
\end{tabular}



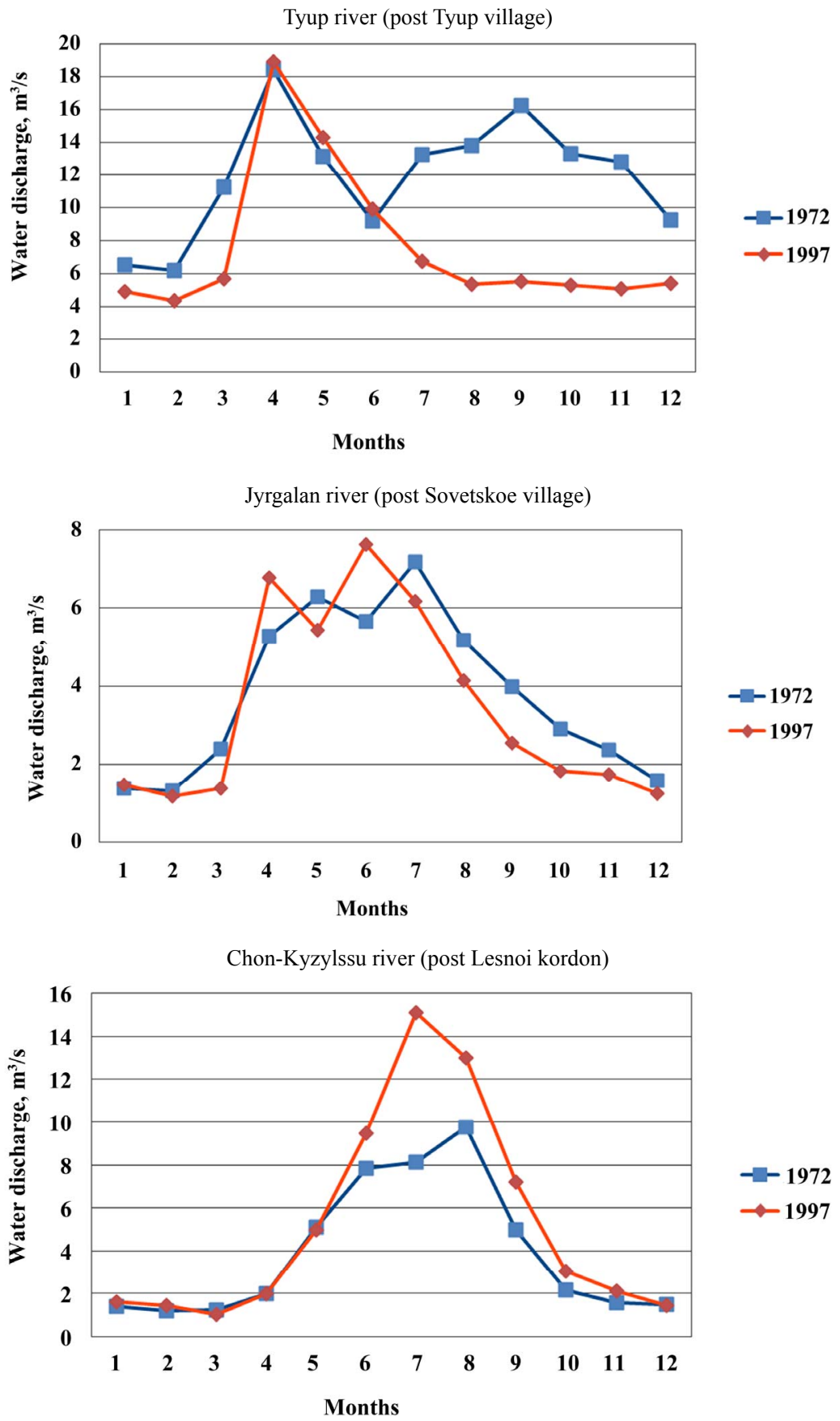

Figure 11. Water discharge of the rivers with the different types of feeding in cold 1972 and hot 1997.

feeding type Tyup river (Sarytologoi) and snow-glacier feeding type Jyrgalan river (Sovetskoe) decreases by $0.14 \mathrm{~m}^{3} / \mathrm{s}$, while on Juuku river with glacier-snow type of feeding, it increases by $3.17 \mathrm{~m}^{3} / \mathrm{s}$. In the temperature range of $0-2.3^{\circ} \mathrm{C}$, July water discharges of Tyup River grow at a higher rate than discharge of the Juuku River. Jyrgalan River discharge exceeds the Tyup River discharge when the temperature is above $2.3^{\circ} \mathrm{C}$ at expense of glacier discharge increase. Temperature increase by
$1{ }^{\circ} \mathrm{C}$ in August generates the decrease in the discharge on Tyup (by $\left.0.59 \mathrm{~m}^{3} / \mathrm{s}\right)$ and Jyrgalan $\left(0.35 \mathrm{~m}^{3} / \mathrm{s}\right)$ rivers, and discharge increase on Juuku River by $2.05 \mathrm{~m}^{3} / \mathrm{s}$ (Figure 13).

The trend of the summer water discharge decrease on Tyup and Jyrgalan rivers connected with the air temperature increase is caused by the evaporation increase in the basins of these rivers, while on Juuku River, the evaporation increase is compensated with excess by the 


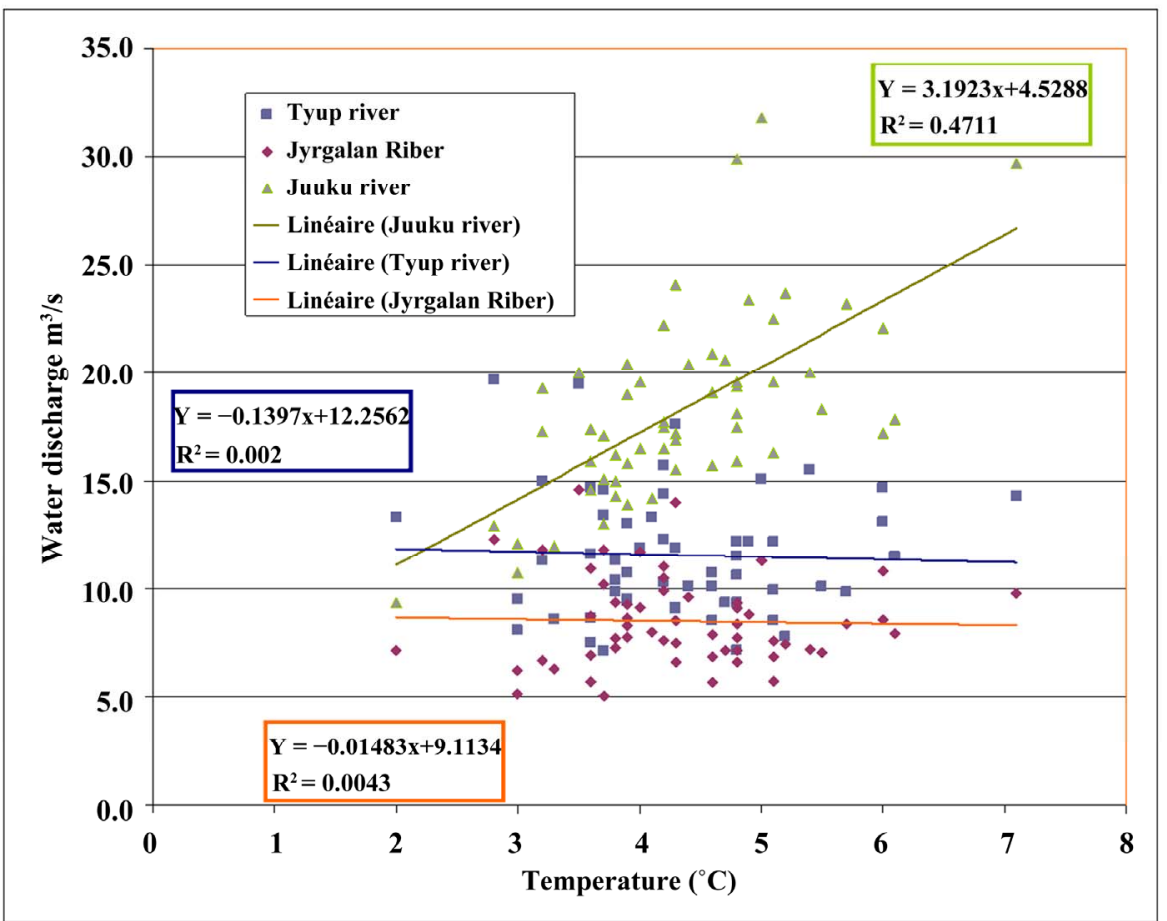

Figure 12. Dependence of the July discharges of the Tyup (Sarytologoi station), Jyrgalan (Sovetskoe station) and Juuku rivers on the air temperature in Tien-Shan meteorological station.

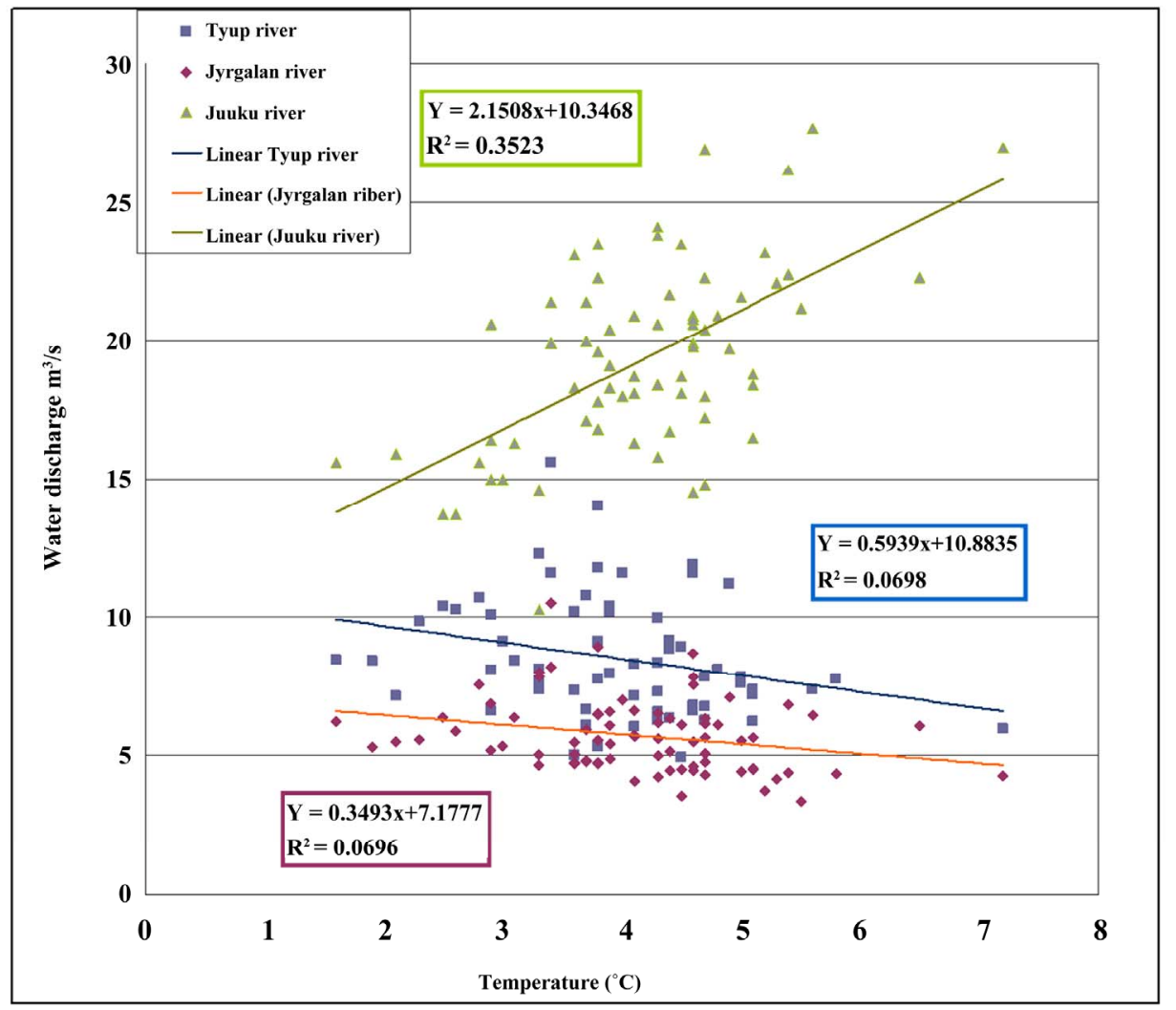

Figure 13. Dependence of August discharge on the Tyup (Sarytologoi station), Jyrgalan (Sovetskoe) and Juuku rivers on the August air temperature at the Tien-Shan meteorological stations. 
glacier discharge increase.

Studies of the modern water discharge increase of Lake Issyk-Kul basin rivers have shown a good dependence on the glaciation area of the river basins (Table 2, Figure 14). Thus, the warming in Juuku River by $1^{\circ} \mathrm{C}$ (with glaciation area $51.6 \mathrm{~km}^{2}$ ) leads to the river discharge increase of up to $3.17 \mathrm{~m}^{3} / \mathrm{s}$, and in Chon-Jargy- lchak River (with the glaciation area $12.8 \mathrm{~km}^{2}$ ), it leads to increase of up to $1.00 \mathrm{~m}^{3} / \mathrm{s}$.

Generally, Lake Issyk-Kul basin has a good correlation between the river discharge increase with air temperature increase by $1^{\circ} \mathrm{C}$ in glacio-nival zone and the glaciation area of river basins (Figure 14).

As snow melting in highlands, the absolute term of the

Table 2. River basins glaciation areas and river discharge accretion under temperature warming by $1^{\circ} \mathrm{C}$.

\begin{tabular}{|c|c|c|c|c|c|}
\hline \multirow{2}{*}{ River } & \multirow{2}{*}{ Glaciation area, $\mathrm{km}^{2}$} & \multicolumn{4}{|c|}{ Discharge accretion, $\mathrm{m}^{3} / \mathrm{s} / 1^{\circ} \mathrm{C}$} \\
\hline & & VI & VII & VIII & IX \\
\hline Tyup & 0.5 & 0.37 & -0.14 & -0.59 & -0.14 \\
\hline Turgen-Aksuu & 33 & 1.86 & 1.53 & 0.94 & -0.01 \\
\hline Aksuu & 69 & 1.64 & 1.43 & 1.25 & 0.44 \\
\hline Chon-Kyzylsuu & 45.3 & 1.54 & 2.15 & 1.64 & 0.59 \\
\hline Kichi-Kyzylsuu & 4.12 & 0.04 & 0.17 & 0 & 0.65 \\
\hline Juuku & 51.6 & 2.01 & 3.17 & 2.03 & 0.69 \\
\hline Chon-Jargylchak & 12.8 & 0.51 & 1 & 0.68 & 0.28 \\
\hline Barskoon & 34.6 & 1.11 & 2.1 & 1.71 & 0.45 \\
\hline Tossor & 20.58 & 0.1 & 0.69 & 0.36 & 0.09 \\
\hline Aksai & 45 & 0.33 & 1.37 & 1.85 & 0.54 \\
\hline Cholpon-Ata & 11.1 & 0.45 & 0.54 & 0.41 & 0.14 \\
\hline Chon-Aksuu & 64.9 & 0.94 & 1.46 & 1.52 & 0.61 \\
\hline Aksuu & 9.6 & 1.51 & 0.81 & 0.66 & 0.31 \\
\hline Chon-Oruktuu & 0 & -0.08 & -0.14 & -0.15 & 0.04 \\
\hline Oytal & 0 & 0.13 & 0.1 & 0 & 0.06 \\
\hline
\end{tabular}

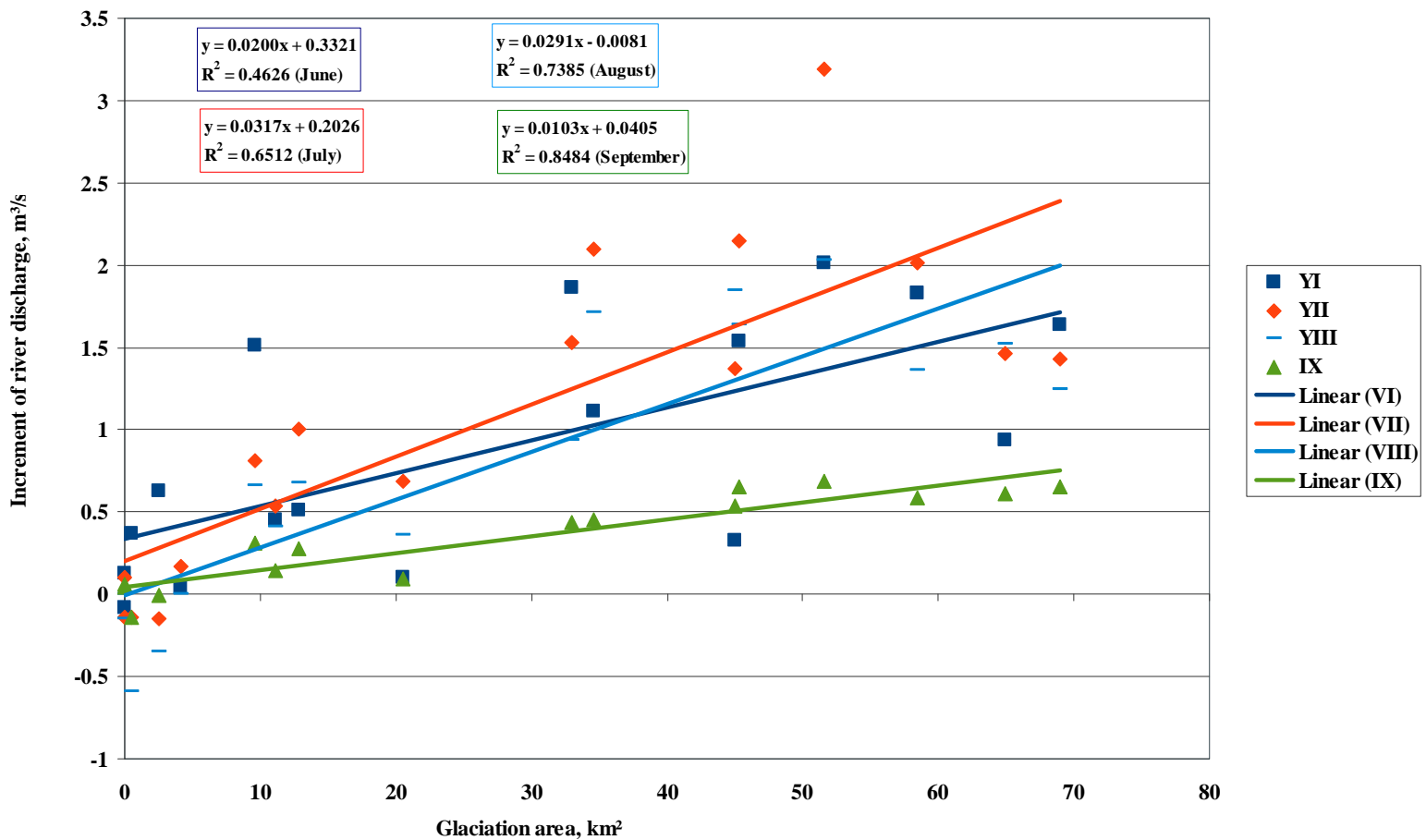

Figure 14. Dependence of river discharge accretion in June, July, August and September on the glaciation's area of the river basins with temperature increase by $1^{\circ} \mathrm{C}$ at the Tien-Shan meteorological stations. 
constraint equations decreases from $0.33 \mathrm{~m}^{3} / \mathrm{s}$ in June, $0.20 \mathrm{~m}^{3} / \mathrm{s}$ in July to $0 \mathrm{~m}^{3} / \mathrm{s}$ in August and September, and the correlation coefficient increases.

The total average annual inflow from the discharge forming area from 17 rivers is $63.79 \mathrm{~m}^{3} / \mathrm{s}$, and the inflow of all the Lake Issyk-Kul basin rivers is $123 \mathrm{~m}^{3} / \mathrm{s}$. In 1942-1972, the discharge from all rivers in the Issyk-Kul basin was $118 \mathrm{~m}^{3} / \mathrm{s}$, while in the period 1973-2008 it was $128 \mathrm{~m}^{3} / \mathrm{s}$. The increase of the river discharge inflow during the last period by $10 \mathrm{~m}^{3} / \mathrm{s}$ or by $8.5 \%$ can be attributed to the increasing glacier discharge. A.N. Dikih and L.L. Dikih [10] noted that for the highland of the Chon-Kyzylsuu River, the contribution of the snow melting during the period of 1973-1991 decreased by $9 \%$ in comparison with the period of 1948-1972; the contribution of summer precipitation decreased by $8 \%$, and annual total layer of the discharge from the non-glacier surface decreased from 631 to $579 \mathrm{~mm}$ or by $8.2 \%$. In this case, Chon-Kyzylsuu River discharge increased at the expense of glacier discharge.

Thereby, we can assume that the increasing of Lake Issyk-Kul basin rivers discharge at the current stage occurs mainly due to the glacier constituent, which was caused by the global warming and active glacier melting during 4 months from June to September. $60 \%$ - 70\% of the annual discharge takes place during this period.

The annual discharge of all rivers in Lake Issyk-Kul basin has good correlation with the annual air temperature at the Kyzylsu MS. According to the linear association equation of these parameters, a $1^{\circ} \mathrm{C}$ increase in the temperature causes an increase in the river discharge by $8.6 \mathrm{~m}^{3} / \mathrm{s}$, or the lake level increment by $44 \mathrm{~mm} /$ year in conversion to the lake area. The root mean square error of the equation is $\mathrm{m}= \pm 5.44 \mathrm{~m}^{3} / \mathrm{s}$ and the relative error is $8.42 \%$.

The features of the vertical distribution of glaciers in Lake Issyk-Kul basin are as follows: in the conditions of climate warming and recession of glaciers, the glacial discharge will grow to the altitude of the maximum distribution of glaciation, which is located at $3920 \mathrm{~m}$ (Table 3) [11]. Currently, the average elevation of the glaciers' ends in the basin is about $3700 \mathrm{~m}$.

The data in Table 3 refer to the mid-1950s, and, unfortunately, we do not know the current information on the state of glaciers in Lake Issyk-Kul basin. But the existing trend of the river discharge increase shows that the glaciers have not yet reached the elevation of maximum glaciation area.

Currently, the annual increase in river discharge is $0.022 \mathrm{~km}^{3}$. The increase in glacier discharge will continue so far as the glaciers will recede to the maximum elevation of the glaciation's area, located at $3920 \mathrm{~m}$, and after this mark, the glacial discharge will decrease.

During 36 years - from 1972 to 2008, about 16\% of the volume of all Lake Issyk-Kul basin glaciers have melted. If current trends persist, the glaciers will melt entirely by 2050 . After glaciation decay, the river discharge will completely depend on precipitation mode. This will cause a considerable redistribution of the intraannual discharge at expense of glacier discharge losses during the hot period of the year.

\section{EVAPORATION}

Evaporation was calculated for the Karakol MS, using the formula of N.N. Ivanov:

$$
E=0.0018(25+T)^{2}(100-a)
$$

where $E$ - monthly evaporation ( $\mathrm{mm}), T$-average monthly air temperature $\left({ }^{\circ} \mathrm{C}\right)$, a-average monthly air humidity $(\%)$.

Due to climate warming, the annual average value of evaporation, calculated on the basis of the data from Karakol meteorological station, during the period of 19731996 was $63 \mathrm{~mm}$ more than in 1942-1972 period. Evaporation trends in June, July, August and September have good synchronization with the air temperature trends.

The current temperature increase causes an increase in evaporation. The temperature increase by $1{ }^{\circ} \mathrm{C}$ causes an increase in evaporation from Lake Issyk-Kul water area by $88 \mathrm{~mm}$, which exceeds twice the increase in river influx under the similar increase in temperature.

The global climate warming is also accompanied by the evaporation increase in river basins. According to the detailed water balance studies in the high-altitude zone

Table 3. Information about Lake Issyk-Kul basin glaciers in the middle of the 1950s.

\begin{tabular}{cccccccccccc}
\hline & $\mathrm{K}$ & $\mathrm{S}$ & $\mathrm{V}$ & $\mathrm{AAR}$ & $\mathrm{S}^{\mathrm{m}}$ & $\mathrm{L}^{\mathrm{m}}$ & $\mathrm{T}^{\mathrm{m}}$ & $\mathrm{H}^{\min }$ & $\mathrm{H}$ & $\mathrm{H}^{\mathrm{f}}$ & $\mathrm{H}^{\operatorname{maxS}}$ \\
\hline Whole basin & 834 & 650.40 & 29.443 & 0.53 & 0.78 & 1.47 & 45.3 & 3020 & 3679 & 3880 & 3924 \\
Kungei-Alatoo & 159 & 140.30 & 6.127 & 0.56 & 0.72 & 1.31 & 42.8 & 3320 & 3745 & 3996 & 3939 \\
Terskei-Alatoo & 675 & 510.10 & 23.316 & 0.52 & 0.80 & 1.52 & 46.0 & 3020 & 3658 & 3845 & 3913 \\
\hline
\end{tabular}

where $\mathrm{K}$ - the number of glaciers; $\mathrm{S}$ - total area of glaciers $\left(\mathrm{km}^{2}\right)$; V-total glaciers volume $\left(\mathrm{km}^{3}\right)$; AAR - the share of accumulation area in total area; $\mathrm{S}_{\mathrm{m}}$ glacier's average area $\left(\mathrm{km}^{2}\right) ; \mathrm{L}_{\mathrm{m}}$ —glacier's average length $(\mathrm{km}) ; \mathrm{T}_{\mathrm{m}}$ - glacier's average sickness $(\mathrm{m}) ; \mathrm{H}_{\text {min }}$ - minimum elevation of the lowest ends of glaciers (m); $\mathrm{H}$-average elevation of the glaciers' end, $\mathrm{H}_{\mathrm{f}}$-average-weighted height of the firn line based on the glaciers' area (m); $\mathrm{H}_{\mathrm{maxS}}-$ height of the maximum of all glaciers area distribution based on the altitude $(\mathrm{m})$. 
of the Terskei-Alatoo range by A.N. Dikih [12], there was revealed a linear dependence of evaporation on air temperature. The increase in summer temperatures by $0.6^{\circ} \mathrm{C}$ increased the evaporation rate by $14 \%$.

\section{PRECIPITATION}

Moisture-laden atmospheric flows coming into the Tien Shan region mainly from the west and northwest, intercepted by the outer ridges (Kyrgyz and Fergana ranges). Inner Tien Shan, like Lake Issyk-Kul Basin, is located in the "rain shadow" of these ranges.

The greatest portion of precipitation falls in the East of Lake Issyk-Kul basin. It is known that a part of precipitation, which form the inner hydrological cycle, is formed by the surface evaporation from the Lake Issyk-Kul. The other part, which comes from outside of basin, forms the external hydrological cycle. The annual precipitation figures at San-Tash and Chon-Ashuu meteoro-logical stations, located in the most humid East part of Lake Issyk-Kul basin at altitude 2236 and $2794 \mathrm{~m}$, have a good correlation with the precipitation at the Tien-Shan meteorological station, located outside the basin in Inner Tien-Shan (Figure 15).

The good correlation of precipitation at the meteorological stations, located in Lake Issyk-Kul basin (SanTash, Chon-Ashu meteorological stations) and outside (Tien-Shan), indicate that the precipitation in the basin is mainly determined by the processes of the external hydrological cycle.

The average annual precipitation, according to the data from 9 meteorological stations in the Inner Tian-Shan from 1966 to 1998 , demonstrates a decreasing trend at the rate of $1.44 \mathrm{~mm} /$ year (Figure 16). During this period, there was noted a trend of Lake Issyk-Kul water level decrease at the rate of $4 \mathrm{~cm} /$ year. In this case, the years with higher precipitation in the Inner Tien-Shan (1969, $1968,1981,1986,1987,1993,1998)$ correspond to the years of the lake level increase.

The annual discharge of 17 rivers with dominant glacier-snow feeding type has poor correlation with precipitation, but the Tyup River of a snow feeding type has a good correlation with the precipitation and river discharge during the hydrological year (October through September) (Figure 17).

The Tyup River discharge is formed not solely by the precipitation, but also by evaporation. Under the annual river discharge in Sarytologoi station of $8.2 \mathrm{~m}^{3} / \mathrm{s}$, the layer of the annual discharge on $513 \mathrm{~km}^{2}$ is $500 \mathrm{~mm}$. Thereby, in Tyup River basin, total annual precipitation, according to San-Tash MS, is $800 \mathrm{~mm}$, and evaporation is $380 \mathrm{~mm}$. Precipitation $(500 \mathrm{~mm})$, which exceeds evaporation, forms the river discharge.

The comparative analysis of chronological variations of the Tyup river discharge and Lake Issyk-Kul water level variations shows that Lake Issyk-Kul water level increases were occurring during the Tyup River average annual discharge at $9 \mathrm{~m}^{3} / \mathrm{s}$ and more. Based on this, we make the conclusion that in the Tyup River basin, out of the economic activity zone, as in whole Issyk-Kul basin, from 1941 to 1993 moisture deficit was observed. This is supported by negative trend of the annual river discharge as well as the overall lake level decrease. Lake Issyk-Kul

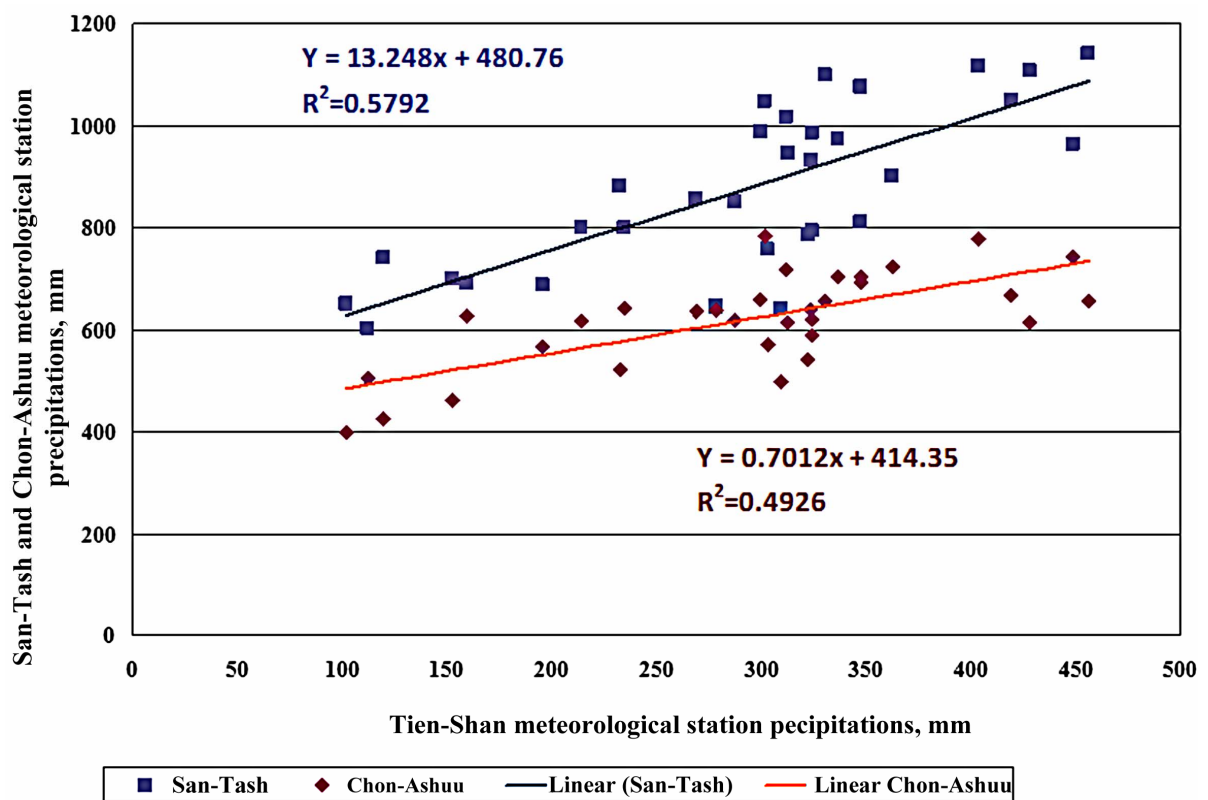

Figure 15. Graph of the correlation between hydrological year precipitations in Tien-Shan, San-Tash and Chon-Ashuu meteorological stations. 


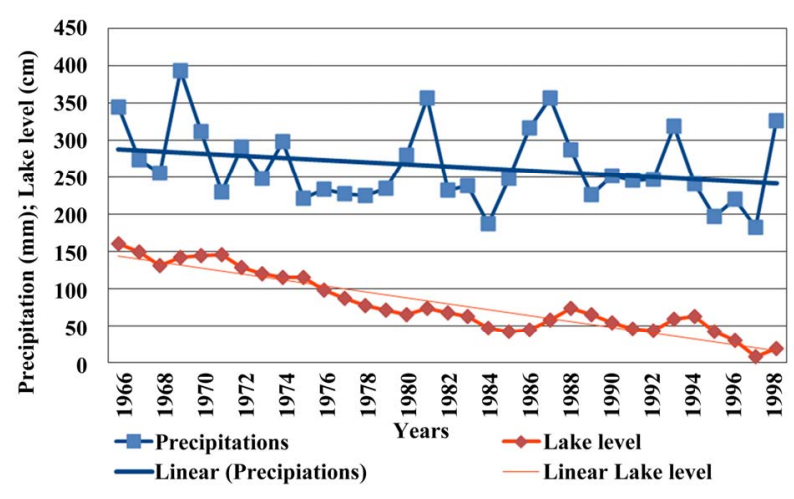

Figure 16. Averaged annual precipitation in Inner Tien-Shan and Issyk-Kul Lake level variation.

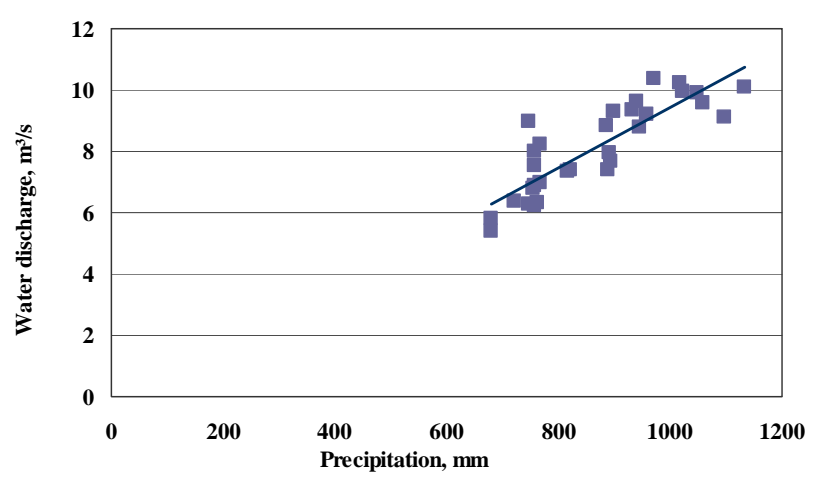

Figure 17. Graph of the relationship between precipitation in San-Tash meteorological station and the discharge of the Tyup River (Sarytologoi) during the hydrological year.

water level would be almost stable, if normal discharge of the Tyup River increases by $0.8 \mathrm{~m}^{3} / \mathrm{s}$ (which means that discharge layer (X-E) increases by $50 \mathrm{~mm}$ ).

Analysis of intra-annual distribution of the precipitation in 2 periods (before and after 1998) in high-altitude meteorological stations, which located in Kyrgyz and Fergana ranges and which are serve as block in the way of the North and West air masses, shows current increasing of the precipitation in Lake Issyk-Kul basin (Figure 18) associated with the activation of the North and North-West moisture-laden flows, which penetrates to Lake Issyk-Kul basin from the Kyrgyz range.

\section{WATER INTAKE FOR IRRIGATION}

The basin has a long history of irrigation. The first irrigation channels in mountain areas were built by Kalmyks in middle Ages. Some of them are still called Kalmyk channels. P.P. Semenov, who visited Lake Issyk-Kul in 1856 and 1857 , noted "... everywhere where is the possibility to split one from the numerous rivers flowing to the Lake Issyk-Kul into channels, the horticulture as well as arable farming find no obstacles" [6].

Irrigated agricultural areas in the beginning of the XX century were 6500 ha. At the beginning of the 1990s, this area had increased by 2.5 times and reached 168,902 ha in 1993; however, by 1997 the irrigated area had reduced to 154,000 ha [13].

The water diversion for irrigation in the beginning of the last century was about $0.3 \mathrm{~km}^{3} /$ year, while in $1980 \mathrm{~s}$ it was $1.4-1.5 \mathrm{~km}^{3} /$ year. In $2000 \mathrm{~s}$ water intakes for irrigation dropped by $45 \%-50 \%$.

Irrevocable water losses of irrigation in 1970-1980s were about $50 \mathrm{~mm} /$ year. They are now appreciably decreased.

\section{LAKE ISSYK-KUL LEVEL VARIATIONS AND WATER BALANCE}

The long-term course of the lake level variations is shown in Figure 19. According to observations of the lake hydrological posts, between 1927 and 2011 the Issyk-Kul lake level has decreased by $2.4 \mathrm{~m}$ in total; however, there were shorter periods of transgression during this time.

The period of Lake Issyk-Kul water level increase corresponds to the years with the positive balance mass of Abramov glacier, located in Alay range. Such humid years were 1969, 1981, 1987, 1993, 1998 (Figure 7). The exception is 1972 with poor precipitation, but cold summer. During that year, Lake Issyk-Kul water level significantly decreased because of the low river discharge, and the Abramov glacier mass balance was positive because of the weak ablation. Therefore, Lake Issyk-Kul water level increase associated with the periods of high humidification over the whole Tien-Shan, and to the processes of the external moisture exchange.

The fluctuation of Lake Issyk-Kul water balance presents great interest in two periods: 1942-1997, when water level decreased with the trend of $5 \mathrm{~cm}$ per year, and 1998-2005, when the water level increased at $11 \mathrm{~cm} /$ year; as well as occasional years: 1997, when lake level decreased by $23 \mathrm{~cm}$, and 2003, when the level increased by $22 \mathrm{~cm}$ (Table 4).

According to Table 4, total discharge from the discharge forming area in 1998-2005, when the Lake IssykKul water level increased by $87 \mathrm{~cm}$, exceed the discharge of the previous period 1942-1997. At that time precipitation increased by $60 \mathrm{~mm}$; average annual temperature exceed the norm by $0.7^{\circ} \mathrm{C}$; maximum values of the intra-annual lake variation moved from the August to September, and in some years (1999 and 2005) even to the October.

In the exceptionally hot year of 1997 , when the annual air temperature exceeded the norm by $1.6^{\circ} \mathrm{C}$ and the total precipitation was less than $150 \mathrm{~mm}$, Lake Issyk-Kul water level decreased by $230 \mathrm{~mm}$. In 2003, the average annual air temperature was higher than the norm by $0.2^{\circ} \mathrm{C}$, but precipitation was above the norm by $110 \mathrm{~mm}$ and 2.3 times more than in 1997. In such meteorological condi- 


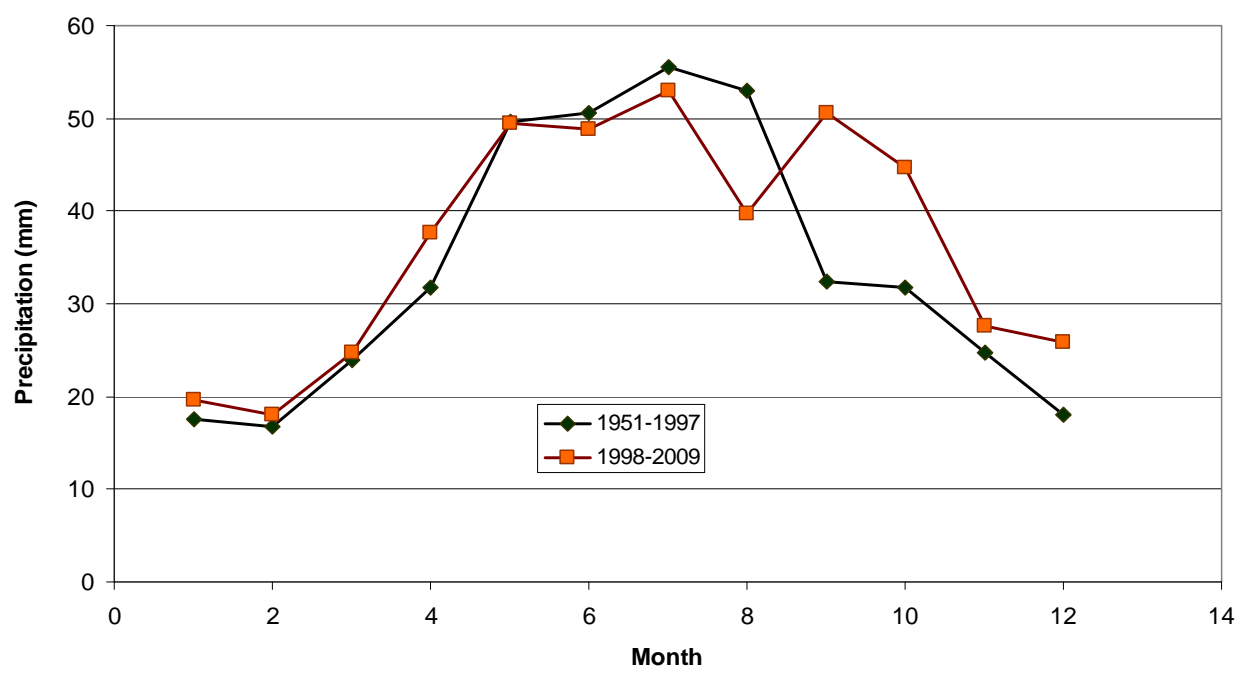

Figure 18. Intra-annual distribution of the precipitation in two periods in Kyzylsuu meteorological station.

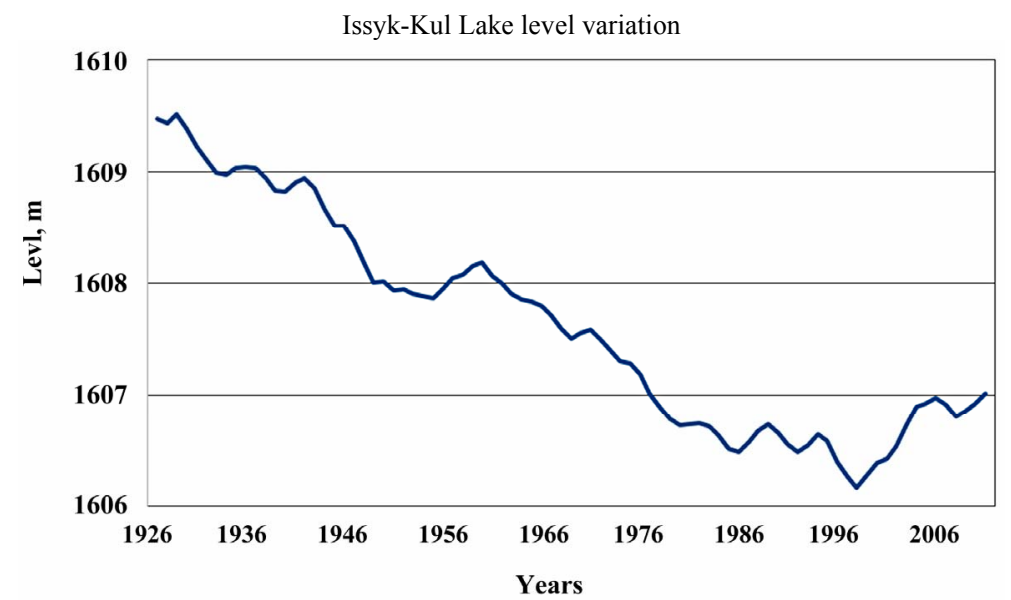

Figure 19. Lake Issyk-Kul water level variation.

Table 4. Lake Issyk-Kul water balance in some periods and years, $\mathrm{mm}$.

\begin{tabular}{lcccc}
\hline & $1942-1997$ & $1998-2005$ & 1997 & 2003 \\
\hline Inflow & 610 & 760 & 670 & 790 \\
Precipitation & 280 & 340 & 160 & 370 \\
Income & 890 & 1100 & 830 & 1160 \\
Outcome (evaporation + irrigation losses) & 940 & 990 & 1060 & 940 \\
Level increment & -50 & 110 & -230 & 220 \\
\hline
\end{tabular}

tions, the lake level increased to $22 \mathrm{~cm}$.

If the long-term climatic conditions remain unchanged (precipitation of 1.28 of norm, annual temperature higher by $0.2^{\circ} \mathrm{C}$ above the norm as observed in 2003), in 50 years Lake Issyk-Kul water level will increase by $11 \mathrm{~m}$ and reach the Kutemaldy discharge threshold and submerge the human settlements and recreational areas at the Holocene terrace of the lake. At the climatic conditions of the 1997 (precipitation is 0.6 of the norm, annual air temperature higher by $1.6^{\circ} \mathrm{C}$ above the norm) it could decrease by $11.5 \mathrm{~m}$ over the same period of time. Both of these events scenarios will have catastrophic consequences for Lake Issyk-Kul shores.

\section{CONCLUSIONS}

1) Global warming, which takes place in Tien-Shan after the 1972, entails Lake Issyk-Kul water temperature increase down to the maximum depths.

2) Glacier discharge increasing due to the global 
warming induces regular increase of the surface discharge.

3) Increase in temperature by $1{ }^{\circ} \mathrm{C}$ leads to increase in river discharge by $8.6 \mathrm{~m}^{3} / \mathrm{s}$ or increment of the lake level to $44 \mathrm{~mm} /$ year were recalculated to the lake area.

4) About $16 \%$ of the glaciers in the basin have melt away over 36 years (1972-2008). At present trends, glaciers will completely be recalculated by 2050 . After deglaciation, the river discharge will depend entirely on precipitation regime. In this case, a considerable redistribution of the discharge within the year will happen due to the glacier discharge losses at the hot season.

5) Global warming results in increased evaporation. In this case, the temperature increase by $1^{\circ} \mathrm{C}$ results in the increase of evaporation from Lake Issyk-Kul surface by $88 \mathrm{~mm}$, which twice exceeds the increase in river discharge through the same increase in temperature.

6) Precipitation in the Lake Issyk-Kul basin is mostly determined by the processes of the external hydrological cycle.

7) The current autumn precipitation increase is associated with the activation of the North and North-West moisture-laden air flows, and penetrates into Lake Issyk-Kul basin from the Kyrgyz range.

8) The Lake Issyk-Kul water level increase is associated with the periods of increased humidification over the whole Tien-Shan and is determined by the moisture exchange processes.

\section{REFERENCES}

[1] Mamatkanov, D.M., Bazhanova, L.V., Romanovsky, V.V. and Dikih, A.N. (2004) Modern climate change and the response of different types of water resources of Kyrgyzstan. Water Resources in Central Asia, 1, 25-30.

[2] Romanovsky, V.V., Kuzmichenok, V.A., Mamatkanov,
D.M. and Podrezov, A.O. (2005) Everything about IssykKul Lake. Encyclopedic reference on nature and ecology of the lake and lobe. Bishkek, 406.

[3] (2005) Rhythm of the climate changes and the Issyk-Kul Lake variation. Study of hydrodynamics of the Issyk-Kul Lake using isotopic methods. Bishkek: "Ilim", 81-89.

[4] Romanovsky, V.V. (1992) On Decline of Issyk-Kul Lake Level. Journal of Lake Sciences, 4, 43-53.

[5] (1946) Issyk-Kul Lake. Leningrad: Gidrometeoizdat, 148.

[6] Romanosky, V.V. (1990) Issyk-Kul Lake as a natural complex. Frunze: Ilim, 168.

[7] Romanovsky, V.V. (2002) Water level variations and water balance of Lake Issyk-Kul: Lake Issyk-Kul: Its Natural Environment. IV. Earth and Environmental Sciences, 13, 45-59.

[8] Romanovsky, V.V. (2002) Water level variations and water balance of Lake Issyk-Kul: Lake Issyk-Kul: Its Natural Environment. IV. Earth and Environmental Sciences, 13, 45-59.

[9] Voyeikov, A.I. (1948) Climates of the Earth, especially of the Russia. Selected Writings, 1, 163-671.

[10] Dikih, A.N. and Dikih, L.L. (2000) The ratio of the discharge components of the glacier type of feeding rivers in the presence of global warming (by the example of the Chon-Kyzyl-Suu). Kyrgyzstan ecology: Problems, forecasts, recommendations. Publishing House "Ilim", Bishkek, 81-86.

[11] Kuzmichenok, V.A. (2003) Mathematical and cartographic modeling of possible changes in water resources and glaciers of Kyrgyzstan due to climate change. Vestnik of the Kyrgyz, Slavic University, 53-64.

[12] Dikih, A.N. and Mikhailov, V.I. (1976) Glacier regime and water balance of Terskei Alatau range. Nauka, Moscow, C132.

[13] (2009) Second national communication of the Kyrgyz republic on the UN framework convention on climate change. Bishkek, 213. 